\title{
THE IMPACT OF THE SOCIOLINGUISTIC ENVIRONMENT ON THE STATE LANGUAGE PROFICIENCY OF CHILDREN FROM ETHNIC MINORITIES IN A PRESCHOOL EDUCATIONAL INSTITUTION
}

\author{
Dace Markus, Dina Bethere \\ Liepaja University, Latvia
}

\begin{abstract}
The article discusses the impact of the daily language choice of ethnic minority children on Latvian language skills in a preschool educational institution. The aim of the study is to explore the impact of the daily language choice of ethnic minority children on Latvian language skills in a preschool educational establishment, surveying the children's parents. Within the project LAMBA (2015-2017), the researchers Olga Ureka, Dace Markus and Anna Vulane adapted a survey elaborated by Sharon Unsworth (Utrecht Bilingual Language Exposure Calculator (UBiLEC): Questionnaire and notes on Completing the Excel file) to Latvian for surveying bilingual parents. Sharon Unsworth has developed this method in Utrecht to use as a survey for parents of bilingual children. The set of questions is included in the survey which is based on the previous experience of educators and linguists in work with children. The questions included are about children's linguistic surroundings at home, in preschool setting, in other activities and during free time. The answer options included in the tables allow to investigate parents' opinions about children language comprehension and application quality and frequency, but in the survey tables we can obtain also quantitative data about the use of language and children's linguistic environment. Employing UBiLEC, an internationally approbated survey adapted to Latvian for parents of bilingual children, the Latvian language skills of ethnic minority children are compared in the preschool groups where children daily use Latvian or Russian. The topicality of the issue is intensified by the requirement, in force from September 1, 2019, that in Class 1 of all ethnic minority schools $50 \%$ of learning must take place in the state language; therefore, it is important to make sure that preschool-age children are prepared for learning in Latvian. In recent years, there has been a tendency for the ethnic minority parents to enrol their children not only in the preschool groups taught in Russian, but also in Latvian. Parents' survey data show that the ethnic minority children who attend a Latvian preschool group are linguistically ready to continue their education in Latvian or bilingually - the same as children with Latvian as their mother tongue, but if Russian is used as a language of instruction, the lack of Latvian sociolinguistic environment becomes a major obstacle for acquisition the necessary Latvian
\end{abstract}


language proficiency. This research was done in National Research Programme "Latvian Language" Nr. VPP-IZM-2018/2-0002.

Keywords: Latvian language, minorities, parents `survey, preschool, sociolinguistic environment.

\section{Introduction}

The aim of the study is to explore the impact of the daily language choice of ethnic minority children on Latvian language skills in a preschool educational establishment, surveying the children's parents. As since September 1, 2019, it is established that in Class 1 the learning process takes place $50 \%$ in Latvian and 50\% in ethnic minority language, acquiring also one foreign language (usually English), it is important to make sure that ethnic minority preschool children are prepared for such curriculum (Regulations Regarding the State Guidelines for Pre-school Education and the Model Pre-school Education Programmes, November, 2018). Until now, in Latvia, the UBiLEC method is employed only for surveying those ethnic minority parents (including foster parents and guardians), whose children attend preschool educational institutions with Russian as language of instruction. The result of our previous research based on recordings reflects the situation in preschool institutions in following way: "The results obtained highly demonstrate that, for children visiting groups using the Latvian language every day, the Latvian language skills are significantly better than the language skills of minority children visiting groups using Russian-dominated language every day" (Markus, Taurina, Zīrina, 2021, p. 144). That is one of the reasons why we decided to investigate parents' opinions to the learning issues of the State language. In recent years, there has been a tendency for ethnic minority parents to enrol their children in groups with Latvian as a language of instruction. In this study, to assess how important is a socio-linguistic environment for learning a language in preschool education, besides the above mentioned surveying of bilingual parents, we compare the Latvian language skills of ethnic minority preschool children in groups of Latvian and Russian as a language of instruction. The parents of two Liepaja preschool educational institutions agreed to the survey. There are 20 preschool education institutions in Liepaja: two of them are entirely ethnic minority preschools, eight implement both Latvian and ethnic minority programmes, but the other preschools operate in Latvian. 


\section{Research Methodology}

In Latvia, there are not many early language assessment tools; mostly they are speech tests of various scopes, based on questions about the pictures. In the scientific literature, there are also many references to the role of parental observations and surveys in determining the language skills of children, disorders or further learning strategies (Kristoffersen, Simonsen, 2012; Law, Roy, 2008; Shannon, Milian, 2002; Thal, O'Hanlon, Clemmons, Fralin, 1999; Vulāne, Urek, Markus, 2016 etc.). Withing the project LAMBA (2015-2017), the researchers Olga Ureka, Dace Markus and Anna Vulane adapted a survey elaborated by Sharon Unsworth (Utrecht Bilingual Language Exposure Calculator (UBILEC): Questionnaire and notes on Completing the Excel file) to Latvian for surveying bilingual parents. The findings on problems that arose while adapting the survey have been described in publications (Markus, 2018, p. 158-159). "This survey has been tested in Latvian settings but has not been widely applied yet. The adequacy of the answers, of course, depends on the responsible attitude of the parents, but in general, the extensive first-time application of the survey in Latvia can provide new ontolinguistic and sociolinguistic discoveries in Latvian linguistics and pedagogy" (Markus, 2018, p. 166).

\section{Results}

The respondents: 25 ethnic minority parents of children who attend the preschool groups with Russian as a language of instruction, and 13 ethnic minority parents of children who attend the preschool groups, where the learning takes place in Latvian. The content of the survey was previously coordinated with the State Inspectorate for Protection of Children's Rights, the State Data Protection Inspectorate, and the data protection specialist of Liepaja University. The parents completed the questionnaires individually in the presence of researchers.

All children involved in the study receive the required preschool education: in Latvian groups all learning takes place in Latvian, but in the Russian-speaking group Latvian is used only twice a week during Latvian language lessons (30-45 minutes), but other teaching and daily communications take place in Russian. Posters, photo corners and other visual environment-design materials also enhance the Russian language environment in these groups. No statistically significant differences were found in relation to the child's gender and parents' level of education $(p>.05)$. The summary of the survey results for the groups with Russian as language of instruction shows that the knowledge of Latvian for these children is very poor. To the question "How well does your child speak Latvian?" 15 parents 
answered, "hardly any fluency" six parents indicated "limited fluency" three parents - "fairly fluent" but only one parent answered that his/her child is "equally fluent in Latvian and Russian" (See Figure 1).

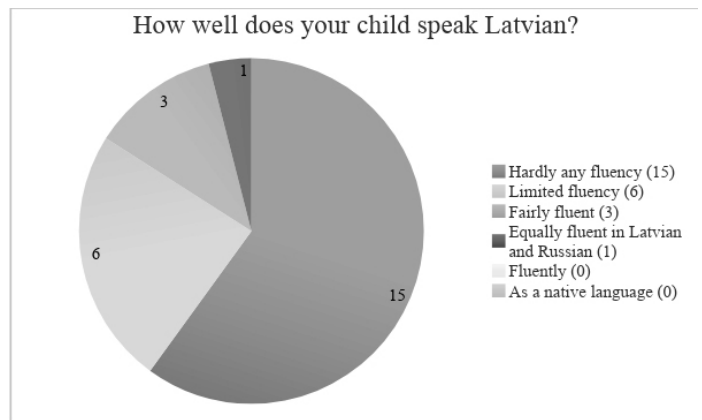

Figure 1. Latvian language proficiency of children from ethnic minorities in groups with Russian as a language of instruction

In the groups with Latvian language of instruction, the ethnic minority children are regularly exposed to conversations both with the teachers and other Latvian children, also the games played, and all daily issues solved in Latvian. As a result, the ethnic minority children are fully engaged with other Latvian-speaking children, therefore it is not surprising that the parents have highly valued the Latvian language skills of their children: 8 out of 13 surveyed parents admitted that their children are equally fluent in Latvian and Russian, thus it can be assumed that these children are symmetrically bilingual, while five parents even assessed their children's Latvian language skill as fluent (see Figure 2).

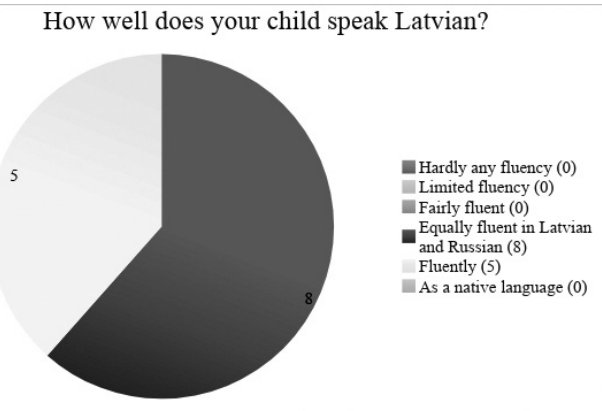

Figure 2. Latvian language proficiency of minority children in groups with Latvian as a language of instruction

At the same time, all surveyed parents indicated, that at home their families converse predominantly in Russian, therefore, the children who attend the pre-school group with Latvian as a language of instruction are 
successful bilinguals: they speak Russian at home, but Latvian in their preschool education institution. This was also confirmed by parental answers to the question "How did your child first come into contact with Latvian language?" (See Table 1).

Table 1. Child's first contact with Latvian language

\begin{tabular}{|l|l|c|c|}
\hline No & $\begin{array}{l}\text { Collaboration } \\
\text { partner }\end{array}$ & $\begin{array}{l}\text { Parental answers about } \\
\text { children from groups with } \\
\text { Russian as a language of } \\
\text { instruction }\end{array}$ & $\begin{array}{l}\text { Parental answers about } \\
\text { children from groups with } \\
\text { Latvian as a language of } \\
\text { instruction }\end{array}$ \\
\hline 1. & Mother/guardian & - & - \\
\hline 2. & Father/ guardian & - & - \\
\hline 3. & $\begin{array}{l}\text { Both parents/ } \\
\text { guardians }\end{array}$ & 1 & 3 \\
\hline 4. & $\begin{array}{l}\text { Older brother or } \\
\text { sister }\end{array}$ & 1 & - \\
\hline 5. & Grandparents & - & 3 \\
\hline 6. & Nanny & 1 & - \\
\hline 7. & Preschool teacher & - & 10 \\
\hline 8. & $\begin{array}{l}\text { Latvian language } \\
\text { teacher }\end{array}$ & 19 & - \\
\hline 9. & $\begin{array}{l}\text { Surrounding } \\
\text { language }\end{array}$ & 3 & - \\
\hline
\end{tabular}

In the survey, the parents indicated how well their children know and understand Latvian, thus we compared the correlation between the Latvian language skills of the children as indicated by the parents and various indicators of the language environment (see Table 1, Table 2, Table 3).

All the children of parents involved in this research were born in Latvia. In the Russian-speaking group, most children became acquainted with Latvian for the first time during the 30-45-minute Latvian language lesson (19), some (3) heard it in the surrounding environment, one child from a nanny, one - from an older brother or sister, and only one (who was assessed as equally fluent in both languages) - from both parents, but grandparents were not mentioned at all (see Table 1). In the group where learning is conducted in Latvian, most children (10) heard Latvian for the first time from their preschool teacher, 3 children - from both parents and both grandparents, even when the home language for them is Russian (see Table 1). Thus, for both groups of children, the preschool educational institution (teachers or assistants) have had the greatest stimulus for paying attention to Latvian language. 
In order to discover more about the influence of the family on Latvian language skills, we used the table, adjusted from UBiLEC survey, with the task "Think about the people who have a regular contact with your child at home. How often do each of these people speak Latvian and Russian to your child?" (See Tables 2 and 3).

Table 2. Parental answers about children from groups with Russian as a language of instruction

\begin{tabular}{|c|c|c|c|c|c|c|c|}
\hline & 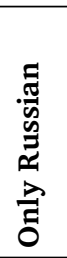 & 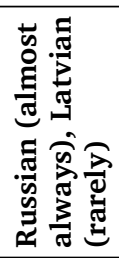 & 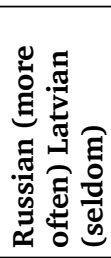 & 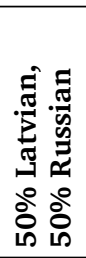 & 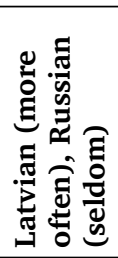 & 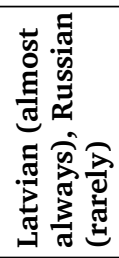 & 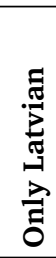 \\
\hline Mother & 24 & & & 1 & & & \\
\hline Father & 24 & & & 1 & & & \\
\hline Sister/brother & 22 & & 3 & & & & \\
\hline Grandmother & 23 & & & & & & \\
\hline Second grandmother & 23 & & & & & & \\
\hline Grandfather & 23 & & & & & & \\
\hline Second Grandfather & 19 & & & & & & \\
\hline Nanny & & & 1 & & & & \\
\hline
\end{tabular}

Table 3. Parental answers about children from groups with Latvian as a language of instruction

\begin{tabular}{|c|c|c|c|c|c|c|c|}
\hline & 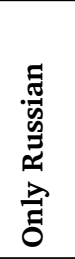 & 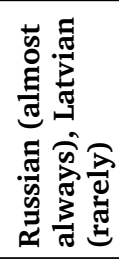 & 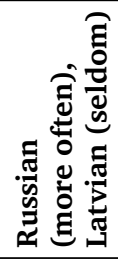 & 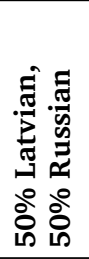 & 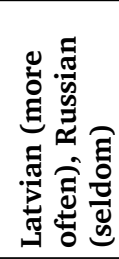 & 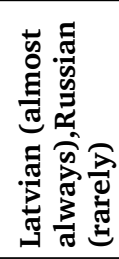 & 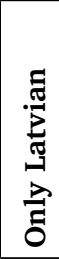 \\
\hline Mother & 8 & 3 & 2 & & & & \\
\hline Father & 12 & & 2 & & 1 & & \\
\hline Sister/brother & & 4 & 4 & & & & \\
\hline Sister/brother & & & 3 & & & & \\
\hline Grandmother & 12 & & & & 1 & & \\
\hline Second grandmother & 13 & & & & & & \\
\hline Grandfather & 10 & & 2 & & & & \\
\hline Second Grandfather & 12 & 1 & & & & & \\
\hline Nanny & 2 & & & & & & \\
\hline
\end{tabular}


Parental answers about the use of language in the family slightly differ in Russian language groups and in Latvian language groups (see Tables 2 and 3) there are more cases when Latvian language is used in the family (5 mothers, 2 fathers, 11 brothers or sisters, 3 grandfathers); but only one grandmother and one father use more often Latvian than Russian (grandfather passed away in this family). In general, the data revealed in Tables 2 and 3, illustrates that the home language of both groups of respondents is Russian.

\section{Discussion}

In this article, we compare the survey of parents of 25 preschool children from ethnic minority population who learn in preschool education groups with Russian as a medium of instruction, and the survey of parents of 13 preschool children from ethnic minority population who learn in preschool education groups with Latvian as a medium of instruction. All children of the surveyed parents are born in Latvia. For surveying the parents, the internationally acknowledged bilingual parents' survey UBiLEC, adapted to Latvian language, was employed. Our results show that the findings about Latvian language skills significantly differ depending on which preschool group the child attends. In the groups with Russian as a language of instruction, the children's Latvian language skills are assessed as following: the dominating response was "hardly any fluency" (15 children), 6 parents stated, "limited fluency" 3 - "fairly fluent" and only one answer was "quite fluent". The responses to the question "How did your child first come into contact with the Latvian language?" reveal the reasons for poor Latvian language skills, as 19 of 25 surveyed children have heard Latvian for the first time from their Latvian language teacher in preschool, where the length of the session is $30-45$ minutes twice a week. In the case when a child speaks both Russian and Latvian, there is a full bilingualism at home; this child speaks mostly Latvian to her parents but Russian to her grandparents, as grandfather does not speak any Latvian. In the groups with Latvian language of instruction, the results were very good: five out of 13 parents surveyed indicated that their children are fluent in both Russian and Latvian, while eight parents admitted that their children speak Russian and Latvian equally fluently. Also, for this group of respondents, the preschool education institution - the educators and other Latvian children play an important role in obtaining Latvian language skills, as the parents of these children have indicated that Russian dominates in their families. This finding is reinforced when comparing the parents' responses to the question: "Think about the people who have a regular contact with your child at home. How often do each of these people speak Latvian and Russian 
to your child?" These responses show that in the ethnic minority families with a Russian-language background, the sociolinguistic environment with Latvian as a language of instruction in preschool education institution plays an important role in the acquisition of Latvian language to prepare children for school in the state language.

\section{Conclusions}

The conducted surveys show that a sociolinguistic environment in a preschool educational institution, in groups with Latvian as a language of instruction, plays an important role in preparation Russian speaking children for school in the state language or bilingually. The parents mention the language of instruction in the preschool educational institution, as well as the language used by the preschool teacher and other children, as the most important elements for learning a good Latvian. In the groups with Latvian as a language of instruction, the ethnic minority children speak Latvian both to the teachers and to other Latvian children on a daily basis. The children also experience the environment that is visually designed in Latvian, and fully immerse themselves in the Latvian-speaking group also learning the language. The conversations in Latvian in the family contribute to the proficiency of Latvian, too, although a real bilingualism in conversations of families of ethnic minorities is rare.

Parents' answers reflect the significance of language acquisition, but at the same time in conversations with parents we could ascertain that still large part of families consider learning of the State language in preschool institution as useless (for example, "Everyone in Latvia speaks Russian also"; "Don't forget about native Russian language"; "It is possible to learn in school"; "We don't plan to live in Latvia in the future" etc.). It would be very important to investigate the parents' attitude and to analyse language skills of staff in preschool institutions in follow-up research about language acquisition of minority children.

\section{Acknowledgement}

Thanks to the National Research Programme "Latvian language" No. VPP-IZM-2018/2-0002 about the possibility to conduct the research on Latvian language skills of preschool children from Latvian and ethnic minority groups. 


\section{References}

Kristoffersen, K., \& Simonsen, H. G. (2012). Tidlig språkutvikling hos norske barn: MacArthur-Bates foreldreraport for kommunikativ utvikling. [Early language development in Norwegian children: MacArthur-Bates parental report of communicative development]. Oslo: Novus forlag.

Law, J., \& Roy, p. (2008). Parental report of infant language skills: A review of the development and application of the Communicative Developmental Inventories. Child and Adolescent Mental Health, 13(4), 198-206.

Markus, D. (2018). Prognozējamā neprognozējamïba. Bērnu valoda Latvijā. [Predictable unpredictability. Children's Language in Latvia]. Zinātniska monogrāfija. Rīga: Zinātne (in Latvian).

Markus D., Tauriņa A., Zīriņa T. (2021). Learning of Latvian Language in Pre-Schools in Linguistically Heterogeneous Situations. In V. Dislere (Ed.), The Proceedings of the International Scientific Conference Rural Environment. Education. Personality, 14. Jelgava: LLU, 138-147. Retrieved from https://lufb.llu.lv/conference/REEP/2021/ Latvia_REEP_2021_proceedings_No14_online.pdf

Regulations Regarding the State Guidelines for Pre-school Education and the Model Pre-school Education Programmes, Cabinet Regulation No. 716 of 21, (November, 2018). Retrieved from https://likumi.lv/ta/en/en/id/303371-regulations-regarding-the-state-guidelinesfor-pre-school-education-and-the-model-pre-school-education-programmes

Shannon, Sh. M., \& Milian, M. (2002). Parents Choose Dual Language Programs in Colorado: A Survey. Bilingual Research Journal. 26(3), 681-696.

Thal, O'Hanlon, Clemmons, Fralin (1999). Validity of a Parent Report Measure of Vocabulary and Syntax for Preschool Children with Language Impairment. Journal of Speech, language, and Hearing Research, 42(2), 482-496.

Unsworth, Sh., (2013). Assessing the role of current and cumulative exposure in simultaneous bilingual acquisition: The case of Dutch gender. Bilingualism: Language and Cognition, 16(1), 86-110.

Vulāne, A., Urek, O., \& Markus, D. (2016). MakArtura-Beitas komunikatīvās attīstības testa (KAT) piemērošana latviešu valodai. [Adaptation of the MacArthur-Beita Communicative Development Test (CAT) to the Latvian language]. SOCIETY. INTEGRATION. EDUCATION. Proceedings of the International Scientific Conference, Vol. II, May $27^{\text {th }}-28^{\text {th }}$, pp. 487-499 (in Latvian).

Latviešu Komunikatīvās attīstibas testa rokasgrāmata (LAMBA). [Latvian Comunicative Development Test Manual (LAMBA)]. Available: http://www.lamba.lv (in Latvian). 